cussion, observations on water diuresis in patients with adrenal insufficiency were described by Dr. A. Slessor, while Dr. M. Ginsburg described experiments on the relation between the adrenals and the rate of disappearance of injected pressor-antidiuretic hormone from the blood in rats.

In the course of both parts of the symposium there were references from time to time to a dictum attributed to a distinguished zoologist not present at the meeting, to the effect that it is not the hormones themselves which evolve but rather the uses to which they are put. The chairman briefly returned to this concept in his final summing-up. He regarded it as inherently improbable and cited a number of facts which suggest that hormones are suitable material upon which the evolutionary process can work. This prompts the thought that if a sequel to this symposium is organized in a few years time-and in view of the evident success of the present one it is to be hoped that this will be the case-then perhaps a suitable theme will be "The Evolution of the Endocrine System".

If the above suggestion is acted upon, it would please many if the sequel were held under the same auspices, for the atmosphere of this symposium was extraordinarily pleasant and all the arrangements reflected great credit upon the originator and organizer, Dr. I. Chester Jones. This was acknowledged in a graceful speech at the end by Prof. Benoit, as was the pleasant hospitality accorded to the participants in functions arranged by the Merseyside Civic Society, the University of Liverpool and Prof. Pumphrey.

By arrangement with the Society for Endocrinology, the proceedings will be published as soon as possible in two volumes (Nos. 4 and 5) of the recently established series of Memoirs of that Society, the Royal Society having made a generous grant towards the expenses of publication.

S. J. Folley

\section{PHYSIOLOGY IN HUNGARY}

$\mathrm{T}$

HE twentieth (anniversary) annual conference of the Hungarian Physiological Society was held during July 8-10 in Budapest, under the presidency of Prof. Brunó Straub, and to mark the occasion the Hungarian National Academy of Sciences invited a number of guests from other countries to attend the meetings and to participate in the discussions. The programme, which contained 128 communications, demonstrated both the high quality of work in progress in the fields of physiology, biochemistry and pharmacology, and also the remarkable number and keenness of the younger generation of Hungarian scientific workers. Besides these papers, which were divided into three concurrent sections, there were plenary sessions, the first being devoted to a general report by Prof. $G$. Romhányi (University of Pécs) on the most recent discoveries relating to biological structure and function, and the others to lectures and communieations by the foreign visitors.

From neighbouring countries came, among others, the Polish biochemists and physiologists, W. Niemerko (now director of the Nencki Institute, soon to return from Lodz to new quarters in Warsaw) and W. Missiuro ; several Czechoslovak guests, including Dr. E. Gutmann (who at one time worked in Oxford) ; the Rumanian medical physiologists, Danielopulo and Julius Nitzulescu; and Prof. Gotséeff, of Bul- garia (one of the pupils of the late Sir Joseph Barcroft). The U.S.S.R. sent Prof. P. S. Kupalov (a former colleague in years gone by of Prof. A. V. Hill), Prof. S. C. Koschtojanz, the comparative physiologist, with the neurologists R. Kavetsky and A. Vorobyov. From the United Kingdom came the present writers, and from Germany the biophysicist Prof. Havermann (Berlin).

For more than twenty-five years, especially since the fundamental work of Szent-Györgyi and Straub in 1941 on the relations of actin and myosin, Hungarian physiology and biochemistry have been renowned for interest in the mechanism of muscular contraction. This was particularly in evidence at the present meetings, and for reasons of personal interest we shall report upon it a little more fully. Subjects which came under lively discussion included the effects of various extractants upon the appearance of muscle fibrils under the polarizing and electron microscopes; the early rapid phase of volume diminution accompanying the action current; the binding of metallic ions (especially $\mathrm{Ca}++$ and $\mathrm{Mg}^{++}$) by actin and myosin; and comparison of these proteins with others in this respect. The binding of $\mathrm{Ca}^{++}$by muscle mitochondria was also reported upon. Interesting discussions were evoked by new investigations of the bound nucleotides in muscle and other cells, not only by Hungarian workers but also by Niemerko from Poland. A further topic was the cholinesterase activity of the mero-myosins prepared by tryptic hydrolysis ; all of it was found to be in the $\mathrm{L}$-mero-myosin just as all the adenosine triphosphatase actuity is in the $\mathrm{H}$-meromyosin. Among the workers presenting these papers were, with their many collaborators, E. Ernst, F. Guba, T. Erdös, G. Feuer, E. Biró, M. Bárányi and E. Varga.

Dr. I. Banga described some recent developments of her work on elastin, particularly in relation to the dependence of its elasticity on provision of water. Since elastin itself cannot bind water, the presence in the neighbourhood of water-binding collagen is essential. Dr. Banga and her husband, Prof. Joseph Baló, who directs one of the institutes of pathology in the University of Budapest, are much concerned with problems such as those of arterio-sclerosis.

Prof. Straub, while maintaining his interest in actin, has turned his attention also to protein synthesis. Papers from his laboratory included those on penicillinase synthesis in $B$. cereus, and on amylase synthesis in pancreas homogenates, in the presence of adenosine triphosphate. Interesting effects of ions on glutamine synthesis were also reported.

At the conclusion of the conference, the foreign visitors, together with some of their Magyar hosts, made excursions to the provinces to see the Freshwater Biological Institute on the shores of Lake Balaton, and the Universities of Pécs and Debrecen. The Biological Station at Tihány, where in the past several British investigators have worked, is in good condition, and in many ways well equipped, especially with a fine library. Under the direction of Dr. Bela Entz and Mr. I. Konok, work is proceeding on the hydrobiology of the lake with reference to the fisheries, and on the comparative physiology of invertebrates, including insect hormones. There is space for about twenty workers, and the collecting facilities include a good motor-cruiser.

The University of Pécs was first founded in A.D. 1367; but ceased to exist when the great majority of its students were killed in resisting the 
advance of the Turks-it was not re-founded until the present century. The town lies all on the slopes of a pleasant range of hills, and still has two mosques and a minaret among its architectural remains. The University consists primarily of the Faculties of Medicine and Law. Scientifically, it occupies a special position, as nearly all its professors are Academicians, and the National Academy of Sciences takes a particular interest in its progress. In the Department of Physiology, headed by Prof. E. Ernst, visitors were able to seo ingenious apparatus for measurement of rapid volume changes using a piezo-electric quartz membrane, and microcalorimeters for recording heat-production of muscles without contact between the tissue and the thermo-couples. One of the chairs of pathology is held by Prof. C. Donhoffer (a pupil of the late J. J. R. McLeod at Aberdeen); under his leadership interesting work in nutritional science is proceeding, especially on the effects of many different factors on the selection and intake of food by the rat. In the Department of Neuro-physiology (Prof. K. Lissák) much work on conditioned reflexes is under way; this was naturally of great interest to the Russian and Polish specialists. The Institute of Anatomy and Embryology, under Prof. J. SzentAgothay, was also full of activity, mainly on three lines : neuro-hormonal correlations studied by lesions of the central nervous system; a new approach to 'neuro-taxis' in the study of the means whereby outgrowing axons find their way to their presumptive connexions in ganglia or central nervous system; and developmental neuro-anatomy. Here Dr. G. Székely has obtained results of much interest by homoplastic heterotopic $\theta y \theta$ transplantations in the newt, giving reversed reflex reactions to prey after innervation. Learning to overcome this is possible with half an eye but never with a whole one. Lastly, in the Department of Histopathology (Prof: G. Romhányi) work is well advanced on the study of artificial birefringent fibrils of polymerized deoxyribonucleic acid.

Throughout the conference, Magyar hospitality was at its most charming, and the visitors carried away a deep impression of the vitality of Hungarian physiology and biochemistry.

\section{JOSEPH NEEDHAM}

Dorothy M. NeEDhaM

\section{CROSSED LAMELLAR STRUCTURE IN HIGHER PLANTS}

A. B. WARDROP has directed attention to the A existence of crossed lamellar structures in the cell walls of higher plants, such structures having hitherto been known with certainty to occur in some green algæ (Australian $J$. Bot., 2, 2, 154; 1954). When a number of higher plants in which it was considered that this structure might be present were examined, it was demonstrated in the phloem fibres of Vinca major and the tracheidal elements of the aerial root of Alstonia spathulata. In the latter, two types of crossed structure are recognized: in one, bands of laterally associated micro-fibrils c. $0.5 \mu$ wide intersect at variable angles, whereas, in the other, lateral association is complete, forming a crossed lamellar structure which approaches most nearly that occurring in the algæ. In the outer layer of the secondary wall of wood fibres of Eucalyptus elaeophora and $E$. regnans there is inconclusive evidence of a crossed structure similar to that observed in the cell walls of some vessels, which consists of a loosely formed meshwork of aggregates of microfibrils. This structure is considered to be distinct from the crossed lamellar and cross-banded structures. The paper is illustrated by a number of electron micrographs.

The same author has also reported on the mechanism of the surface growth involved in the differ. entiation of fibres and tracheids (ibid., p. 165). An electron microscopic investigation was made of the differentiating xylem elements of Pinus radiata, Eucalyptus elaeophora and Ulmus sp. In the tips of fibres and tracheids there is a tendency for the microfibrils of cellulose to be oriented in the direction of growth. It is considered that this orientation can be disturbed by subsequent dimensional changes in the cell. The thin areas of the differentiating cells which are involved in the so-called 'mosaic growth' have been compared with the regions of the cell wall penetrated by plasmodesmata in the storage parenchyma of potato tubers. The suggestion is made that the thin areas are regions of the cell wall penetrated by plasmodesmata, or are developing primary pit fields. The implications of this concept, with respect to intercellular readjustment and to the differences between fibres and tracheids in extension growth, are discussed.

\section{FORESTRY IN JAMAICA ANNUAL REPORT FOR 1952-53}

IN the annual report of the Forest Department of 1 Jamaica for the year ending March 1953*, allusion is made to the devastation caused by the great hurricane of 1951 and the rehabilitation work, forestry and planting carried out in 1952. Jamaica's forest policy is outlined in the report as follows: protection and development of the Island's natural forest resources, that is, existing forest reserves and future extension thereof; afforestation of suitable accessible areas with the view of increasing timber production and eventually making the Island selfsupporting; encouragement of afforestation and sound forest management on private lands; and research work on sylvicultural and utilization problems.

It is obvious that considerable progress has been made by the Department, as a working plan for the production reserves has been drawn up and is being worked. It provides for three working circles-plantation, improvement and natural forest. The provisions are very similar to the earlier type of working plans drawn up in India and Burma during the latter part of the nineteenth century. However, there is a serious trouble, one which was also experienced in parts of India during the early days of the Department there. The general position regarding forest reserve boundaries, says the Conservator of Forests, continues to deteriorate and is directly attributable to land hunger of an ever-increasing population. Villagers deliberately remove the boundary stones and, when prosecuted, challenge the accuracy of the original survey, thus requiring a new survey to be made. The policy of the Department is

- Forest Department, Kingston, Jamaica, B.W.I. Annual Report for the Year ended 31st March, 1953. Pp. 12. (Kingston, Jamaica : for the Year ended 31st Mart.)
Forest Department, 1953.) 